\title{
ACVR2B wt Allele
}

National Cancer Institute

\section{Source}

National Cancer Institute. ACVR2B wt Allele. NCI Thesaurus. Code C51724.

Human ACVR2B wild-type allele is located within 3p22 and is approximately $29 \mathrm{~kb}$ in

length. This allele, which encodes activin receptor type 2B protein, plays a role in lig and binding interactions pertaining to T GF-beta signal transduction. 